\title{
The association between a journal's source of revenue and the drug recommendations made in the articles it publishes
}

\author{
Annette Becker MD MPH, Fatma Dörter DMD, Kirsten Eckhardt DMD, Annika Viniol MD, Erika Baum MD, \\ Michael M. Kochen MD MPH, Joel Lexchin MD, Karl Wegscheider PhD, Norbert Donner-Banzhoff MD MSc
}

See related commentary by Kesselheim, page 534

Competing interests:

Annette Becker was a

consultant for Grünenthal

$\mathrm{GmbH}$, from whom she has

also received a speaker's

fee. Erika Baum is the

vice-president of the

German College of General

Practitioners and Family

Physicians. Michael

Kochen is a member of

the Drug Commission of

the German Medical

Association and is editor of

the journals Zeitschrift für

Allgemeinmedizin and

Arznei-telegramm. Joel

Lexchin has worked as a

consultant for Apotex Inc.

and the Government of

Canada, has provided expert

testimony for the law firm

of McGinnis, Lochridge

and Kilgore LLP and is a

board member for Healthy

Skepticism. Karl

Wegscheider is a member

of the Drug Commission of

the German Medical

Association. Norbert

Donner-Banzhoff is a

member of the board for the

German College of General

Practitioners and Family

Physicians and has a spouse

employed by Novartis. No

other competing interests

were declared.

This article has been peer reviewed.

Correspondence to:

Dr. Annette Becker,

annette.becker@staff

uni-marburg.de

CMAJ 2011. DOI:10.1503 /cmaj.100951

\section{- Abstract}

Background: There is evidence to suggest that pharmaceutical companies influence the publication and content of research papers. Most German physicians rely on journals for their continuing medical education. We studied the influence of pharmaceutical advertising on the drug recommendations made in articles published in 11 German journals that focus on continuing medical education.

Methods: We conducted a cross-sectional study of all of the issues of 11 journals published in 2007. Only journals frequently read by general practitioners were chosen. Issues were screened for pharmaceutical advertisements and recommendations made in the editorial content for a specified selection of drugs. Each journal was rated on a five-point scale according to the strength with which it either recommended or discouraged the use of these drugs. We looked for differences in these ratings between free journals (i.e., those financed entirely by pharmaceutical advertising), journals with mixed sources of revenue and journals financed solely

by subscription fees. The journals were also screened for the simultaneous appearance of advertisements and recommendations for the same drug within a certain period, which was adjusted for both journal and class of drug.

Results: We identified 313 issues containing at least one advertisement for the selected drugs and 412 articles in which drug recommendations were made. Free journals were more likely to recommend the specified drugs than journals with sources of revenue that were mixed or based solely on subscriptions. The simultaneous appearance of advertisements and recommendations for the same drug in the same issue of a journal showed an inconsistent association.

Interpretation: Free journals almost exclusively recommended the use of the specified drugs, whereas journals financed entirely with subscription fees tended to recommend against the use of the same drugs. Doctors should be aware of this bias in their use of material published in medical journals that focus on continuing medical education.

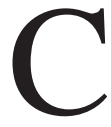
linicians rely heavily on the information provided by journals for their continuing medical education. ${ }^{1}$ In Germany, the circulation of educational medical journals seems to exceed that of medical journals that emphasize research.

There has been some debate over whether commercial interests influence the content of scientific publications. Evidence from a systematic review suggests that authors' conflicts of interest are significantly associated with positive results in the studies they publish. ${ }^{2,3}$ There is additional evidence that pharmaceutical companies pressure leading journals or journals with high impact to avoid publishing content that is contrary to the marketing interests of the company. ${ }^{4}$

Drug advertisements are used by doctors as a source of information, and they have been shown to influence the prescribing behaviour of physicians. ${ }^{5}$ However, the quality of drug advertisements placed in major journals is not an adequate basis on which to rely when deciding whether to prescribe a specific medication. ${ }^{6,7}$ In 2004, Reuter and Zitzewitz ${ }^{8}$ described an advertising-related bias in the financial media. The authors found that publications were more likely to print articles recommending funds from companies that had placed the most advertisements in the publication in the previous 12 months.

Little is known about such corporate influence on educational medical journals. Educational medical journals are often sent to physicians free of charge. These so-called "free journals" depend entirely on advertising to generate their revenue. Only a few educational medical journals are financed entirely by fees paid by their subscribers. We investigated whether a 
journal's source of revenue was associated with recommendations for or against the use of specific drugs in the editorial content of the journal.

\section{Methods}

Using advice from four general practitioners, each of whom runs a practice and is involved with the training of medical students, we identified 11 German educational medical journals that are widely read by general practitioners. The journals were divided into three classes according to their source of revenue: "free journals," which are completely financed by paid advertisements; "mixed-revenue journals," which are financed by both subscription fees and paid advertisements; and "subscription journals," which are completely financed by subscription fees.

All of the issues published in 2007 in the selected periodicals were included in the search for eligible articles and advertisements (Table 1).

We selected nine innovative drugs or classes of drug that are used to treat common illnesses and that were heavily promoted at the start of the sampling period (Table 2). These drugs were chosen for two reasons: they were still protected by patents and were more expensive than other drugs used to treat the same conditions, and there was some con- troversy over either their effectiveness or the range of indications for which they should be prescribed. All advertisements and articles related to these drugs and published in the selected journals in 2007 were recorded. Articles that referred to other drugs or articles that did not make any recommendations for the specified drugs were excluded.

Articles were electronically scanned and presented to raters in a neutral layout. Each article referring to one of the selected drugs was evaluated for the strength of its recommendation for or against the use of the drug. The evaluations were done using an ordinal five-item scale ranging from -2 to +2 . A positive integer indicated a strong or moderate recommendation for use of the drug, a score of zero indicated a neutral statement, and a negative integer indicated a moderate or strong recommendation against use of the drug. The evaluation was conducted by two dental students who had been trained to use the rating system and who were blind to the selected journals (interrater reliability, Cohen's $\kappa=0.73$ ). Ratings followed a standardized procedure and were based on the content and titles of the articles, as well as on the way in which the authors worded their recommendations for or against the use of the selected drugs.

We compared the strength of recommendations across classes of journal revenue sources

Table 1: Characteristics of 11 journals commonly read by general practitioners in Germany that were included in the study*

\begin{tabular}{|c|c|c|c|c|}
\hline Journal title & Circulation & $\begin{array}{c}\text { No. of issues per } \\
\text { volume (frequency) }\end{array}$ & $\begin{array}{c}\text { Frequency of } \\
\text { advertisements }\end{array}$ & Available by subscription \\
\hline \multicolumn{5}{|l|}{ Free journals } \\
\hline Ärztezeitung & 63900 & 226 (daily) & ++ & Usually free \\
\hline Medical Tribune & 67000 & 52 (weekly) & ++ & Usually free \\
\hline Der Hausarzt & 55000 & 20 (biweekly) & ++ & Usually free \\
\hline Der Allgemeinarzt & 50000 & 20 (biweekly) & ++ & Usually free \\
\hline $\begin{array}{l}\text { Munchener Medizinische } \\
\text { Wochenschrift - Fortschritte der } \\
\text { Medizin }\end{array}$ & 60000 & 51 (weekly) & ++ & Usually free \\
\hline \multicolumn{5}{|l|}{ Mixed-revenue journals } \\
\hline Deutsches Ärzteblatt & 403000 & 52 (weekly) & + & $\begin{array}{l}\text { Yes, and free to members of } \\
\text { the German Medical } \\
\text { Association }\end{array}$ \\
\hline \multicolumn{5}{|l|}{ Subscription journals } \\
\hline Arzneiverordnung in der Praxis & 3500 & 4 (quarterly) & 0 & Yes \\
\hline Zeitschrift für Allgemeinmedizin & 3500 & 12 (monthly) & 0 & $\begin{array}{l}\text { Yes, and free to members of } \\
\text { the German College of } \\
\text { General Practitioners and } \\
\text { Family Physicians }\end{array}$ \\
\hline Arznei Telegramm & Not available & 12 (monthly) & 0 & Yes \\
\hline Der Arzneimittelbrief & 14000 & 12 (monthly) & 0 & Yes \\
\hline Tägliche Praxis & Not available & 4 (quarterly) & 0 & Yes \\
\hline
\end{tabular}


using a linear mixed model with revenue class as the factor and journals within revenue classes as the random effect to account for any potential cluster effect caused by multiple recommendations appearing within the same journal.

We did a logistic regression analysis to determine whether a recommendation for a drug was more likely to appear if an advertisement for that drug was present in the same issue of the journal. This analysis referred only to issues of the free journals. The presence of a recommendation for a specific drug was the dependent variable. Independent regressors included the drug (clopidrogel was used as the reference), the journal and the presence of an advertisement for the drug. The influence of an advertisement varied according to drug and journal because we included the corresponding interaction terms. We used backward selection so that only significant interaction terms were retained in the model (log-likelihood ratio test, $p<0.05)$. Three analyses were done: one for ads in the same issue; one for ads in the previous, same or subsequent issue; and one for ads in up to five previous issues (depending on the number of issues of the journal published per year).

\section{Results}

We screened 465 issues from 11 periodicals for each of the 9 drugs or drug classes. The characteristics of each journal are given in Table 1. We identified 638 advertisements for the selected drugs (312 issues, ranging from 14 to 161 per journal) and 297 articles that made recommendations for or against the use of the selected drugs (250 issues, ranging from 2 to 105 per journal) (Table 2). More than one advertisement of the same drug in the same issue was counted only once. We identified 592 advertisements and 256 articles making recommendations concerning the selected drugs in free journals, 46 advertisements and 7 articles in the mixed-revenue journal and 34 articles with rec-

Table 2: The selected drug and drug classes and the frequency with which they were advertised or recommended in articles published in the selected educational journals

\begin{tabular}{|lcc|}
\hline Drug or class of drug (indication) & $\begin{array}{c}\text { No. of issues in which } \\
\text { advertisements for the } \\
\text { selected drug appears } \\
n=638\end{array}$ & $\begin{array}{c}\text { No. of issues in which at least } \\
\text { one article recommended use of } \\
\text { the selected drug } \\
n=412\end{array}$ \\
\hline AChE inhibitors (dementia) & 36 & 21 \\
\hline $\begin{array}{l}\text { Ezitimibe (hypercholesterolaemia) } \\
\text { Incretin mimetics/enhancers (diabetes) }\end{array}$ & 75 & 18 \\
$\begin{array}{l}\text { Clopidogrel (prophylactic for } \\
\text { cardiovascular disease) }\end{array}$ & 102 & 79 \\
\hline $\begin{array}{l}\text { Glitazones (diabetes) } \\
\text { Varenicline (smoking cessation) }\end{array}$ & 38 & 38 \\
\hline $\begin{array}{l}\text { Duloxetine (depression, urge } \\
\text { incontinence) }\end{array}$ & 56 & 29 \\
$\begin{array}{l}\text { ARBs and sartans (hypertension, heart } \\
\text { failure) }\end{array}$ & 3 & 6 \\
\hline Insulin analogues (diabetes) & 174 & 42 \\
\hline Note: AChE = acetylcholinesterase, ARBs = angiotensin receptor blockers. & \\
\hline
\end{tabular}

Table 3: Strength of recommendations for or against use of the selected drugs, by journal's source of revenue

\begin{tabular}{|c|c|c|c|c|c|c|c|}
\hline Source of revenue & $n$ & \multicolumn{5}{|c|}{ Strength of recommendation; no. (\%) of articles } & Mean score* \\
\hline $\begin{array}{l}\text { Paid advertisements and } \\
\text { subscription fees }\end{array}$ & 7 & $1(14.3)$ & $1(14.3)$ & 0 & $1(14.3)$ & $4(57.1)$ & 0.86 \\
\hline Subscription fees & 34 & $10(29.4)$ & $18(52.9)$ & $3(8.8)$ & $3(8.8)$ & 0 & -1.03 \\
\hline
\end{tabular}


ommendations but no advertisements in the subscription-based journals. Table 2 shows the frequency with which advertisements and articles concerning each of the selected drugs appeared.

The results of our main analysis, the comparison of the strength of recommendations to support the use of a drug across journal classes, are given in Table 3. Readers of the free journals received almost exclusively positive messages (ratings of +1 and +2 ) about the selected drugs, and these drugs were mentioned more often in the free journals than in the journals that depended on subscription fees or a mixture of subscription fees and paid advertisements for their revenue. Mean strengths of recommendations were 1.90 for free journals, 0.86 for mixed-revenue journals and -1.03 for subscription-based journals (Table 3 ).

Logistic regression modelling showed that, among the free journals, the frequency of recommendations depended on both the journal and the drug (Table 4). Glitazones were three times more likely (odds ratio [OR] 2.61, 95\% confidence interval $[\mathrm{CI}]$ 1.59-4.27) to be recommended than clopidogrel, the reference drug, as were incretin mimetics (OR 3.15, 95\% CI 1.93-5.14), and angiotensin-receptor blockers were about five times more likely to be recommended than the reference drug (OR 5.18, 95\% CI 3.20-8.40). In two of the free journals studied, Munchener Medizinische Wochenschrift and Der Allgemeinarzt, the presence of an advertisement for a specific drug more than doubled the probability of a positive recommendation for that drug appearing in the same issue of the journal. The observed associations disappeared when looking at the pervious, same or subsequent issues or at the previous five issues.

\section{Interpretation}

Our study showed that recommendations for the use of a drug depended on the source of the journal's funding. Free journals almost exclusively endorsed the use of the selected drugs, whereas journals that relied exclusively on subscription fees for their revenue were more likely to recommend against the use of the same drugs.

A survey of Canadian general practitioners found that they were unlikely to consider journals that did not undergo a peer review process (typically journals sent to them free of charge) as credible sources of information. However, more than half of the doctors surveyed said that they had used free journals as a source of information during the previous month. ${ }^{9}$

In 2006, Lexchin and Light ${ }^{10}$ stated that revenue from journal advertising was one of the most important factors associated with commercial bias. ${ }^{11,12}$ Using print material as the sole source of information for continuing medical education seems ineffective, but the integration of such material into multimedia interventions has been shown to change the behaviour of physicans in practice. ${ }^{13,14}$ Print media are still among the most important sources of information for doctors. ${ }^{1}$

Rennie and Bero summarized the characteristics of free journals as follows: they publish more advertisements than editorial content, they are not owned by societies, they do not publish original work, the articles they publish are not cited, they are subjected to no standard level of peer review, and they are deficient in critical editorials and correspondence. ${ }^{15}$ It is also worth noting that the conflicts of interests of either the authors or the editors are not declared in these journals. Munchener Medizinische Wochen-

Table 4: Association between recommendations for the use of selected drugs and their advertisement in the same issue of free journals, adjusted for drug class and journal

Variable $\quad$ Adjusted OR $(95 \% \mathrm{Cl})$

Drug or class of drug

AChE inhibitors $\quad 0.73(0.39-1.33)$

Ezitimibe $0.64(0.34-1.20)$

Duloxetine $0.18(0.07-0.47)$

Glitazones $2.61(1.59-4.27)$

Incretin mimetics/enhancers $\quad 3.15$ (1.93-5.14)

Insulin analogues $1.64(0.97-2.78)$

Varenicicline $0.91(0.51-1.63)$

ARBs and sartans $\quad 5.18(3.20-8.40)$

Clopidogrel* $\quad 1.00$

Journal

Ärztezeitung $0.36(0.23-0.56)$

Medical Tribune

$0.93(0.56-1.56)$

Munchener Medizinische

$0.67(0.39-1.14)$

Wochenschrift - Fortschritte der

Medizin

Der Hausarzt

$1.76(0.96-3.22)$

Der Allgemeinarzt

$2.43(1.46-4.05)$

Presence of specific

advertisement (any drug) by

journal (interaction terms)

\begin{tabular}{ll} 
Ärztezeitung & $0.62(0.38-1.03)$ \\
\hline Medical Tribune & $1.62(0.95-2.76)$ \\
$\begin{array}{l}\text { Munchener Medizinische } \\
\text { Wochenschrift - Fortschritte der }\end{array}$ & $2.19(1.25-3.82)$ \\
Medizin & \\
\hline Der Hausarzt & $0.67(0.30-1.47)$ \\
\hline Der Allgemeinarzt & $2.77(1.04-7.35)$
\end{tabular}

Note: $\mathrm{AChE}=$ acetylcholinesterase, $\mathrm{ARBs}=$ angiotensin receptor blockers, $\mathrm{Cl}=$ confidence interval, $\mathrm{OR}=$ odds ratio.

*Reference drug. 
schrift invites advertisers to place their advertisements concurrently with the publication of articles on specific topics. This is sometimes done for a higher fee if the advertisements are placed before or after a related educational article.

\section{Limitations}

Only one journal with a mixed source of revenue was included in our study, which is why our findings are more relevant to free journals and journals that rely exclusively on subscription fees. In addition, we did not account for the content of the advertisements in terms of whether they reported adverse effects or contained black box warnings or other safety information.

To ensure that the raters were blind to the journals they were evaluating, all of the articles were scanned and presented in a neutral layout. However, as they gained experience in the evaluaion process, the raters became able to recognize the type of journal they were reading based on the style of writing.

Our raters were dental students who had no therapeutic experiences with or preferences for the specified drugs that would have biased the collection of data or the rating given to each article. Odds ratios of less than 1.0 that were derived from the logistic regression analyses were probably random effects and should be verified in future studies.

Only German journals were chosen for this study to get a representative sample of educational journals targeting primary care physicians in a single country. An article by Rennie and Bero describes free journals published in the United States. ${ }^{15}$ Those journals shared certain characteristics with the journals analyzed in our study. Therefore, we believe that the results of our study can be generalized to journals published in other countries where the financing of free journals follows a similar model.

\section{Conclusion}

Our study should draw attention to the potential for bias in free journals. These journals counter efforts to inculcate critical reading skills and evidence-based medicine. They take advantage of the struggle that general practitioners face in dealing with the growing complexity of medicine, a constant lack of time and an overload of information. Physicians need to realize that the alternatives are to either pay for journals with objective information or rely on the potentially biased information published in free journals.

\section{References}

1. Vollmar HC, Rieger MA, Butzlaff ME, et al. General practitioners' preferences and use of educational media: a German perspective. BMC Health Serv Res 2009;9:31.

2. Lexchin J, Bero LA, Djulbegovic B, et al. Pharmaceutical industry sponsorship and research outcome and quality: systematic review. BMJ 2003;326:1167-70.

3. Friedman LS, Richter ED. Relationship between conflicts of interest and research results. J Gen Intern Med 2004;19:51-6.

4. Dyer O. Journal rejects article after objections from marketing department. BMJ 2004;328:244.

5. Spurling GK, Mansfield PR, Montgomery BD, et al. Information from pharmaceutical companies and the quality, quantity, and cost of physicians' prescribing: a systematic review. PLoS Med 2010;7:e1000352.

6. Villanueva P, Peiro S, Librero J, et al. Accuracy of pharmaceutical advertisements in medical journals. Lancet 2003;361:27-32.

7. Wilkes MS, Doblin BH, Shapiro MF. Pharmaceutical advertisements in leading medical journals: experts' assessments. Ann Intern Med 1992;116:912-9.

8. Reuter J, Zitzewitz E. Do ads influence editors? Advertising and bias in the financial media. Q J Econ 2006;121:197-227.

9. Angus Reid Group. Credibility and the marketing mix. Toronto (ON): The Group; 1991.

10. Lexchin J, Light DW. Commercial influence and the content of medical journals. BMJ 2006;332:1444-7.

11. Bower AD, Burkett GL. Family physicians and generic drugs: a study of recognition, information sources, prescribing attitudes, and practices. J Fam Pract 1987;24:612-6.

12. Ferry ME, Lamy PP, Becker LA. Physicians' knowledge of prescribing for the elderly. A study of primary care physicians in Pennsylvania. J Am Geriatr Soc 1985;33:616-25.

13. Davis D, Galbraith R. Continuing medical education effect on practice performance: effectiveness of continuing medical education: American College of Chest Physicians Evidence-Based Educational Guidelines. Chest 2009;135:42S-8S.

14. Marinopoulos SS, Dorman T, Ratanawongsa N, et al. Effectiveness of continuing medical education. Evid Rep Technol Assess (Full Rep) 2007;1-69.

15. Rennie D, Bero LA. Throw it away, Sam: the controlled circulation journals. AJR Am J Roentgenol 1990;155:889-92.

Affiliations: From the Department of General Practice, Preventive and Rehabilitative Medicine (Becker, Dörter, Eckhardt, Viniol, Baum, Donner-Banzhoff), University of Marburg, Marburg, Germany; the Department of General Practice and Family Medicine (Kochen), University of Göttingen, Göttingen, Germany; the School of Health Policy and Management (Lexchin), York University, Toronto, Ont.; the Department of Medical Biometry and Epidemiology (Wegscheider), University Medical Centre, Hamburg, Germany.

Contributors: Annette Becker and Norbert DonnerBanzhoff planned the study, discussed the results and wrote the manuscript. They take equal responsibility for the integrity of the data and the accuracy of the analysis. Fatma Dörter and Kristen Eckhardt collected and analyzed the data. Michael Kochen, Joel Lexchin and Erika Baum planned the study, discussed the results and revised the manuscript critically. Annika Viniol analyzed the data, discussed the results and revised the manuscript. Karl Wegscheider supervised and conducted the statistical analyses, discussed the results and revised the manuscript. All of the authors approved the final version submitted for publication.

Funding: No direct funding was received for this study. 